Edward Torończak ${ }^{*}$

Warszawa

\title{
Psychologiczne uwarunkowania rozwoju ludzkiej wolności i wyboru zasadniczego czlowieka
}

\section{Wprowadzenie}

Zagadnienie wolności i wyboru człowieka jako zjawiska osobowego nie miało szans pojawienia się w obszarze mechanistycznych (deterministycznych) koncepcji ludzkiego istnienia, które dominowały aż do późnych lat pięćdziesiątych, a nawet do wczesnych lat sześćdziesiątych XX wieku. Dopiero wyłonienie się głównego nurtu psychologii humanistycznej ${ }^{1} \mathrm{w}$ późnych latach pięćdziesiątych, a szczególnie w latach siedemdziesiątych, dało podstawy do zajęcia się problemem wyboru w psychologii. W latach osiemdziesiątych zagadnienie osobowego wyboru stopniowo zostało rozpoznane jako jeden z kluczowych problemów psychologii osobowości. Posiada ono swoje źródło w filozofii egzystencjalno-fenomenologicznej² i akademickiej psychologii, budującej teorie życiowego i spo-

* Dr Edward Torończak SJ, wykładowca w Papieskim Wydziale Teologicznym „Bobolanum” w Warszawie.

${ }^{1}$ Psychologia humanistyczna koncentruje się na możliwościach rozwojowych człowieka. Już od początku lat trzydziestych XX wieku K. Horney głosiła pogląd, że samorealizacja jest podstawową skłonnością istoty żywej. Natomiast A. Maslow wskazywał, w jaki sposób jednostka może stać się szczęśliwa i w pełni zrealizować poprzez pracę. Ich poglądy nawiązują do odkryć i teorii K. Goldsteina na temat samorealizacji. Zaś na początku lat sześćdziesiątych dzięki C. R. Rogersowi psychologia humanistyczna rozprzestrzeniła się poza granice USA. Jej główne przesłanie zaowocowało teorią zdrowej osobowości i koncepcją potencjału rozwojowego organizmu. Por. N. Sillamy, Stownik psychologii, tłum. K. Jarosz, Katowice 1999, s. 236.

${ }^{2}$ Głównymi przedstawicielami tego nurtu w psychologii i psychiatrii są szwajcarscy psychiatrzy L. Binswanger i M. Boss. Z kolei we Wiedniu psychologię egzystencjalną rozwijał V. E. Frankl, a w Paryżu L. Minkowski. Zaś najwybitniejszymi przedstawicielami tego nurtu w psychologii amerykańskiej są R. May, A. Van Kaam i J. Bugental. Pewne wątki egzystencjalno-fenomenologiczne pojawiły się również w pracach polskiego psychiatry A. Kępińskiego. Por. P. K. Oleś, Wprowadzenie do psychologii osobowości, Warszawa 2003, s. 315. 
łecznego zachowania. Psychologowie o orientacji humanistycznej, wychodząc ze stanowiska, że pozytywizm okazał się metodą nieadekwatną w stosunku do człowieka, sięgnęli do takich systemów filozoficznych jak fenomenologia czy egzystencjalizm ${ }^{3}$.

Jak zostało już zauważone, niniejsze rozważania odwołują się do wymiaru interdyscyplinarnego prezentowanego zagadnienia. Trzeba wyraźnie podkreślić, że pojęcie wolności, bezpośrednio związane z problematyką osobowego wyboru, stanowi przedmiot wielu współczesnych refleksji filozoficznych, psychologicznych i pedagogicznych. Zagadnienie to wybrzmiewa również w teologicznej koncepcji wyboru fundamentalnego ${ }^{4}$, rozwijanej w tzw. nowej teologii moralnej. W ujęciu reprezentantów tego nurtu teologii kształtowanie się terminu wolności podstawowej i wyboru fundamentalnego, wynika raczej z podejścia transcendentalnego do działania ludzkiego (K. Rahner, J. Fuchs), niż z podejścia empirycznego $^{5}$. W przekonaniu tych autorów nie chodzi o wolność wyboru (psychologiczną) ani wolność chrześcijańską, działającą dzięki łasce, ale o wolność podstawową (transcendentalną), która jest wolnością o wiele głębiej zakorzenioną w osobie, niedostępną psychologicznemu badaniu. Jest to wolność, która nie tylko umożliwia człowiekowi podejmowanie konkretnych decyzji moralnych, ale pozwala mu na „totalne” samookreślenie siebie jako osoby. Warto jednak zauważyć, że nie wszyscy autorzy idą za transcendentalnym rozumieniem wolności i wyboru zasadniczego człowieka. Przykładem tego jest choćby B. Häring, który w rozważaniach na temat wyboru zasadniczego obficie korzysta z badań psychologii humanistyczno-egzystencjalnej. Odnosi on to pojęcie do rozwoju osobowego człowieka, szczególnie do kształtowania się tożsamości podmiotu, która ma decydujący wpływ na głębokie samookreślenie się człowieka ${ }^{6}$.

Perspektywa interdyscyplinarna pozwala spojrzeć na problematykę rozwoju ludzkiej wolności i wyboru zasadniczego człowieka z różnych stron. W niniejszej refleksji będzie chodziło o uchwycenie wkładu psychologii dla nauki o wychowaniu. Oczywiście interdyscyplinarność omawianej problematyki zakłada, że obie dyscypliny naukowe (psychologia i pedagogika), które się ściśle łączą, dysponują autonomią. Trzeba jednak pamiętać o tym, że interdyscyplinarność

${ }^{3}$ Por. G. Kijewski, Rozwój osobowości w koncepcji A. Maslowa, Życie i Myśl 26 (1976) nr 2, s. 54.

${ }^{4}$ Teoria wyboru fundamentalnego jest rozwijana w tzw. nowej teologii moralnej. Termin wybór fundamentalny może być rozumiany w języku polskim w różny sposób, jako: „,witalne zaangażowanie się w coś”, ,zasadniczy plan życia”, „centrum osoby”, „głębokie ukierunkowanie woli”, „osobowa decyzja za dobrem lub złem”, ,podstawowe zamierzenie”, ,wybór podstawowy”, „wybór zasadniczy”, „opcja fundamentalna”. Por. E. Torończak, Opcja fundamentalna jako „,nowy” paradygmat moralności?, Zeszyty Naukowe KUL 49 (2006) nr 4, s. 82.

${ }^{5}$ Por. J. Fuchs, Libertà fondamentale e morale, w: Esiste una morale cristiana? Questioni critiche in un tempo di secolarizzazione, Roma-Brescia 1970, s. 113-140.

${ }^{6}$ Por. B. Häring, Liberi e fedeli in Cristo. Teologia morale per preti e laici, thum. R. Volante, t. 1, Roma 1980, s. 203-219. 
zakłada rozumienie kształcenia i wychowania człowieka w taki sposób, który będzie odnosił się do obu dyscyplin naukowych ${ }^{7}$. W związku z tym psychologiczne uwarunkowania ludzkiej wolności i wyboru zasadniczego człowieka będa pojmowane w wymiarze pedagogicznym. Rodzi się zatem potrzeba refleksji nad psychologiczno-pedagogicznymi aspektami rozwoju ludzkiej wolności, by odpowiedzieć na pytanie, czy w niektórych nurtach psychologii można mówić o tzw. wyborach głębokich, które nadają zasadniczy kierunek życiu człowieka, kształtując jego postawy i konkretne postępowanie.

\section{Podstawowe elementy integrującej teorii osobowego wyboru}

Niektórzy psychologowie zastanawiają się nad tym, czy ludzka wolność jest w ogóle możliwa. Podkreślają fakt, że ludzkie zachowanie jest określane przez wiele czynników. Dlatego D. A. Leontiev mówi, idąc za C. W. Tagesonem, o tzw. „twardym” determinizmie (np. B. F. Skinner, Z. Freud), który nie pozostawia miejsca na prawdziwą wolność. Jest ona po prostu zwykłą iluzją. Inaczej ma się sprawa z tzw. „miękkim” determinizmem (np. A. Bandura, R. Holt), który nie wyłącza wszystkich stref osobowej wolności, a tym samym wskazuje na wolność ograniczoną ${ }^{8}$.

Jednak bardziej przekonujące antropologicznie wydają się opisy ludzkiej wolności rozwinięte przez przedstawicieli egzystencjalnego nurtu psychologii humanistycznej. D. A. Leontiev na bazie teorii niektórych autorów zajmujących się psychologiczną problematyką wolności i ludzkiego wyboru (np. A. Maslow, V. E. Frankl, E. Fromm, R. May, C. W. Tageson) formułuje swoje wnioski w postaci tzw. siedmiu tez, które ukazują podstawowe elementy i uwarunkowania integrującej teorii osobowego wyboru9 . Już na wstępie można powiedzieć, że według D. A. Leontieva, ludzka wolność posiada możliwość przezwyciężenia różnych form zewnętrznej determinacji aktywności osoby, zachowując w ten sposób możliwość dokonywania osobowych wyborów. Warto jednak bliżej przyjrzeć się jego integrującej teorii osobowego wyboru, by lepiej uchwycić psychologicznopedagogiczne uwarunkowania ludzkiej wolności.

${ }^{7}$ Por. W. Herzog, Pedagogika a psychologia. Zarys wzajemnych relacji, thum. J. Zychowicz, Kraków 2006, s. 197-199.

${ }^{8}$ Zdaniem E. Fromma nie można powiedzieć, by Z. Freud był „twardym” deterministą, ponieważ zakładał on, że przez uświadomienie sobie determinujących uwarunkowań psychologicznych człowiek może uzyskać zdolność wpływu na swoje życie. Zaś „mięki” determinizm, który dopuszcza współistnienie determinizmu i wolności charakterystyczny jest również dla teorii $\mathrm{Hu}-$ me'a i Milla. Por. E. Fromm, Serce człowieka. Jego niezwykła zdolność do dobra i zła, Warszawa-Wrocław 1996, s. 125.

${ }^{9}$ Por. D. A. Leontiev, The Phenomenon of Choice: Preliminary Considerations, w: Sharing Tools for Personal/Global Harmony: First Annual Conference on Conflict Resolution, red. V. Kagan, St. Petersburg 1994, s. 52-64. 
Pierwszym elementem teorii D. A. Leontieva jest transcendencja (transcendence). Pojęcie to związane jest $\mathrm{z}$ wielopoziomowością powiązań przyczynowo-skutkowych mających wpływ na procesy natury ożywionej i nieożywionej. Transcendentna jakość człowieka może dawać mu względną wolność od wielu warstw determinacji, choć nigdy od wszystkich. Człowiek jest rzeczywiście wolny, to znaczy może pozostać na poziomie działania determinowanego przez popędy i okoliczności lub może wznieść się na wyższy poziom autodeterminacji (R. May, E. Fromm). W tym drugim przypadku człowiek posiada rzeczywisty wybór, poprzez który może dokonywać autodeterminacji osobowej. Ona zaś jest jednym z istotnych elementów współcześnie rozwijanej koncepcji wyboru podstawowego.

Drugim elementem omawianej teorii jest odkrycie tzw. ,punktów rozdwojenia" (bifurcation), w których toczący się proces może z jednakowym prawdopodobieństwem przybrać każdy z dwóch możliwych kierunków. Człowiek przeżywa swego rodzaju rozdwojenie przed dokonaniem wyboru, który z kolei owo rozdwojenie usuwa. Wskazuje to na ludzką zdolność do przekraczania determinizmu, która wyjaśnia możliwość ludzkiego wyboru.

Trzecim elementem teorii jest uświadomienie (awareness). Jest to świadomość własnej zdolności wyboru, ale także różnych determinizmów, które mają wpływ na działanie jednostki. Człowiek nie może być wolny, jeśli uważa, że jego działanie jest zdeterminowane, ale także nie może być wolny bez świadomości wpływu na własne działanie różnych bezosobowych sił, gdyż wówczas łatwo może być manipulowany. W tym przypadku wolność można zdefiniować jako zdolność podejmowania decyzji na podstawie znajomości materii ${ }^{10}$.

Czwartym elementem teorii D. A. Leontieva są tzw. zasoby (resources): zewnętrzne (sytuacje) i wewnętrzne (fizyczne i umysłowe zdolności). Na tych dwóch rodzajach zasobów opiera się człowiek w sytuacji wolnego wyboru. Istnieje jeszcze jeden specyficzny rodzaj zasobów, tzw. interaktywnych, które wynikają z pozycji społecznej, przywilejów i osobowych relacji człowieka. To one pomagają człowiekowi osiagnąć dodatkowe cele życiowe. Osiaggnięcie właściwych celów życiowych zakłada porównanie alternatyw (comparing alterntives), co stanowi piąty element teorii osobowego wyboru. W najprostszym rozumieniu wybór jest procesem porównywania wielu zadań i bodźców zgodnie $\mathrm{z}$ jakimś kryterium jasnym dla podmiotu. Można mówić o prostym wyborze (a simple choice) lub o wyborze zorientowanym na znaczenie (meaning-related choice). Istnieją jednak wybory jeszcze bardziej skomplikowane, które decydują o jakości ludzkiego życia. Jest to sytuacja, kiedy ani kryteria, ani alternatywy nie są dane człowiekowi. Musi on niejako samodzielnie je stworzyć lub zaprojektować. W tym przypadku D. A. Leontiev mówi o poznawczym konstruowaniu możliwej przyszłości (construing possible futures), wskazując tym samym szósty element teorii. Można ją porównać do sytuacji zasadniczego wyboru w życiu człowieka, np. wyboru małżeństwa. Ten rodzaj wyboru nazywa on osobowym wyborem (a personal choice). Nale-

${ }^{10}$ Por. tamże, s. 52-64. 
ży jednak odróżnić osobisty wybór (personal choice) od podejmowanej decyzji (decision-making), rozumianej jako pewna forma automatyzmu. Zwykle wolność i osobowy wybór pozytywnie się wzmacniaja, a także warunkują, ponieważ dokonanie wyboru zawierającego elementy wolności umożliwia większą wolność następnego wyboru. Jednak zarówno ludzka wolność, jak i osobowy wybór, nie mogą być zawieszone w „pustce”, ale domagają się jakiegoś uzasadnienia, jakiegoś kryterium aksjologicznego. $\mathrm{Z}$ tego też powodu aksjologiczne uzasadnienie wolności (value justfication of freedom) stanowi ostatni element odnoszący się do integrującej teorii osobowego wyboru ${ }^{11}$.

Według D. A. Leontieva, poradzenie sobie z sytuacją złożoności oraz porównywalności różnych alternatyw (wyborów) domaga się istnienia jakiegoś kryterium. Takie kryterium widzi on, idąc za F. Vasilyukiem, w wartości zasadniczej (value principle). To właśnie na tym poziomie osobowego wyboru można mówić o autodeterminacji osoby, która przekracza zarówno „twardy”, jak i „miękki” determinizm. Ten poziom osoby należy określić terminem duchowość, ale rozumianą jako najwyższy stopień funkcjonowania osobowości. W tej perspektywie pojęcia wolnego wyboru, duchowości, alternatywności, hierarchii wartości mają podobne znaczenie. Opisują one różne strony i alternatywy skomplikowanego mechanizmu ludzkiego samookreślenia ${ }^{12}$. Jest to w rzeczywistości wybór wartości podstawowej, który dokonuje się na najgłębszym poziomie ludzkiej osobowości, dlatego określa się go mianem wyboru zasadniczego. Jednak D. A. Leontiev zwraca uwagę na pewną trudność w pogodzeniu tego zasadniczego wyboru z determinizmem aksjologicznym. Czy wobec tego istnieje możliwość przezwyciężenia tej trudności? Jest to o tyle istotne, że bez rozwiązania tego problemu trudno byłoby mówić, że osoba mogłaby się w sposób wolny samookreślić wobec świata wartości na głębokim poziomie osobowości.

\section{Osobowe samookreślenie jako warunek zasadniczego wyboru czlowieka}

Możliwość przezwyciężenia tej trudności można znaleźć w teorii „wartości-istnienia" zaprezentowanej przez A. Maslowa. Wyróżnia on dwa poziomy motywacji funkcjonujących według odmiennych zasad. Na pierwszym poziomie motywacji mówi on o potrzebach braku (deficiency-needs), czyli takich potrzebach podstawowych, które nie zostały zaspokojone, a uruchamiane są przez niedobór lub brak czegoś. Warto dodać, że motywy deficytowe wygasają, skoro ich brak zostaje zaspokojony. Inaczej działają motywacje na poziomie wyższym samorealizacji - określane jako motywacje wzrostu, ponieważ polegają one na dążeniu człowieka do celów i osobistego rozwoju. Na tym poziomie A. Maslow

\footnotetext{
${ }^{11}$ Por. tamże.

${ }^{12}$ Por. tamże, s. $60-64$.
} 
mówi o motywach istnienia, które aktywizują dążenia do wzrostu, a zwłaszcza realizacji tzw. wartości-istnienia, inaczej mówiąc, wartości bycia, które zalicza się do „metapotrzeb” człowieka. Ich realizacja dokonuje się z chwilą wolnego wyboru wartości, które umożliwiają samourzeczywistnienie osobowe. Osoba motywowana metapotrzebami nie dopytuje się o sens życia, gdyż doświadcza jego oczywistości, nie zastanawia się nad tym, czym jest szczęście, ponieważ odczuwa chwile intensywnego poczucia szczęścia, które określa się mianem doświadczeń szczytowych ${ }^{13}$.

W doświadczeniach szczytowych osoba opuszcza niejako swoje ego, by osiagnąć stan „bez-ja”, który nie jest utratą tożsamości, ale jej punktem szczytowym. W nim człowiek czuje się bardziej odpowiedzialny, aktywny, twórczy, posiadający więcej wolnej woli, a tym samym bardziej decydujący o sobie ${ }^{14}$. Jedną z ważniejszych cech przeżyć szczytowych jest to, że mogą one prowadzić do trwałych i wyraźnie pozytywnych zmian w strukturze osobowości człowieka i w jego światopoglądzie ${ }^{15}$. Dla A. Maslowa doświadczenie szczytowe jest czymś, co wyraża przede wszystkim głębię osoby, która realizuje się w samotranscendencji, w doświadczeniu totalności. Jest „tak” wypowiedzianym z głębi osoby wobec świata wartości. To samookreślenie się jednostki wobec świata wartości dokonuje się poprzez decyzję podstawową, która nadaje zasadniczy kierunek całemu życiu człowieka ${ }^{16}$.

Nie tylko teoria przeżyć szczytowych A. Maslowa, ale także metakliniczne analizy V. E. Frankla rzucają pewne światło dla psychologiczno-pedagogicznego zrozumienia wyboru zasadniczego człowieka. Zdaniem V. E. Frankla, ludzką egzystencję charakteryzują trzy czynniki: duchowość, wolność i odpowiedzialność. Przyjmuje on, obok biologicznego (das Leibliche) i psychicznego (das Seelische), także duchowy (das Geistige) ${ }^{17}$ wymiar w człowieku, ponieważ to „duch instrumentuje ssychophisicum" ${ }^{18}$. Wymiar noetyczny ${ }^{19}$ człowieka posiada W sobie różnorodne właściwości, które poprzez terapię mogą zostać obudzone,

${ }^{13}$ Por. A. Maslow, Motywacja i osobowość, thum. P. Sawicka, Warszawa 1990, s. 72-159; tenże, Obrona i rozwój, w: Przełom w psychologii, tłum. P. Kołyszko, Warszawa 1978, s. 303-321; C. S. Hall, G. Lindzey, J. B. Campbell, Teorie osobowości, Warszawa 2004, s. 439-445.

${ }^{14}$ Por. O. Vedfelt, Poziomy świadomości. Poznaj potencjat swojego umystu, Warszawa 2001, s. 271.

${ }^{15}$ Por. A. Maslow, Religions. Values and Peak-Experiences, New York 1976, s. 66-67.

${ }^{16}$ Por. B. Häring, dz. cyt., s. 218.

${ }^{17}$ Por. V. E. Frankl, Człowiek wolny. Wykłady metakliniczne, thum. R. Czernecki, Z. J. Jaroszewski, w: tenże, Homo patiens, Warszawa 1998, s. 166-172.

${ }^{18}$ Tamże, s. 230.

${ }^{19}$ Określenie „wymiar noetyczny” wywodzi się z greckiego słowa nous, które jest wyrażeniem na określenie rozumu, intelektu, umysłu, myśli, myślenia, zdolności rozumienia i aktywności umysłowej. V. E. Frankl posługuje się tym terminem dla wyrażenia noetycznej głębi i wielkości ludzkiej egzystencji. Innymi słowy, noetyczny wymiar określa specyficznie ludzkie funkcjonowanie, bycie i stawanie się oraz podmiotowo-osobową dynamikę egzystencji. Por. K. Popielski, Noetyczny wymiar osobowości. Psychologiczna analiza poczucia sensu życia, Lublin 1994, s. 36-37. 
aby człowiek mógł na nowo odnaleźć swoją tożsamość. Chodzi o takie właściwości, jak: dążenie do odkrycia sensu (wola sensu), orientacja na cel, ideały, uzdolnienia, wiara religijna oraz sumienie, które mówi człowiekowi, jak postępować w sytuacjach konfliktowych ${ }^{20}$. Stąd też wymiar duchowy stanowi centrum człowieka, które ontologicznie odróżnia go od innych bytów. W ten sposób V. E. Frankl formułuje swoją pluralistyczną, a zarazem wielowarstwową ontologię, która stoi u podłoża zrozumienia problemu rozwoju ludzkiej wolności i zasadniczego wyboru człowieka.

Zdaniem K. Popielskiego, wolność w ujęciu V. E. Frankla jest rozumiana nie tylko jako możliwość czy zdolność wyboru, ale „przede wszystkim jako kwalifikacja konstytuująca osobę". Wynika z tego, że wolność wyboru, czy też ludzka decyzja są czymś wtórnym w odniesieniu do „wyposażenia człowieka w wolność natury osobowej" ${ }^{21}$. Wolność zatem stanowi podstawowe wyposażenie (wartość) i kategorię opisującą ludzką egzystencję, którą można właściwie scharakteryzować jedynie w terminach podmiotu i osoby ${ }^{22}$. V. E. Frankl stwierdza, że „duchowość jest już ex definitione pierwiastkiem wolności człowieka, a [...] dzięki tej duchowej wolności człowiek może podjąć taką lub inną decyzję, za lub przeciw jakiejś pozycji, za lub przeciw jakiejś dyspozycji, jakiejś predyspozycji charakteru lub popędowej skłonności”’23. Tym samym wolność stanowi dla V. E. Frankla esencjalny przejaw duchowości człowieka, dzięki której może on w sposób wolny samookreślać siebie, nadawać swojemu życiu odpowiedni kierunek, zgodny ze światem wartości, które w rzeczywistości go określają. W ujęciu V. E. Frankla wolność z jednej strony jest realną, obiektywnie istniejącą właściwością ludzkiej egzystencji, a z drugiej jest aksjologicznie skierowana. To stanowisko odróżnia Frankla od innych psychologów (np. A. Maslow, C. R. Rogers).

Jednak współczesny człowiek nie zawsze jest świadomy swojej egzystencjalnej wolności, dlatego należy mu ją uświadomić. Może się to dokonać na mocy egzystencjalnej analizy ludzkiej wolności i odpowiedzialności. Ten cel zakłada logoterapia ${ }^{24}$, która jest poszukiwaniem głębszego sensu życia. Przyjmuje ona istnienie nie tylko tego, co duchowe, ale także istnienie „obiektywnego świata sensu i wartości" 25 , w które człowiek może się zaangażować. Dlatego doświadczenie sensu zakłada zawsze moment wyboru, akceptacji i zaangażowania się

${ }^{20}$ Por. V. E. Frankl, Paradoksy szczęścia, tłum. B. Chwedeńczuk, Życie i Myśl 27 (1977) nr 1, s. 33-45.

${ }^{21}$ K. Popielski, dz. cyt., s. 100.

${ }^{22}$ Por. tamże, s. 100

${ }^{23}$ V. E. Frankl, Człowiek wolny..., s. 284.

${ }^{24} \mathrm{Z}$ jednej strony logoterapia ma swoje uwarunkowania filozoficzne - wpływ poglądów M. Schelera, a z drugiej strony psychologiczne - terapia typu C. R. Rogersa. Por. S. Kuczkowski, Psychologia religii, Kraków 1991, s. 163.

${ }^{25}$ V. E. Frankl, Homo patiens. Próba wyjaśnienia sensu cierpienia, tłum. R. Czernecki, Z. J. Jaroszewski, w: tenże, Homo patiens..., s. 22. 
w wartości. Towarzyszy temu moment wartościowania ${ }^{26}$, a więc opowiedzenia się po stronie wartości egzystencjalnie ważnych, co z kolei można określić momentem podjęcia decyzji zasadniczej.

To od zasadniczego wyboru człowieka zależy uczestniczenie w świecie wartości, ignorowanie ich albo opieranie się im. Człowiek nie tylko może wybrać lub odrzucić określoną wartość, ale ma także „wolność wyrzeczenia się swojej wolności" ${ }^{27}$. Dla ludzkiej egzystencji wartości są właściwościami, które ją motywują, aktywizują i ukierunkowują, a jednocześnie dają poczucie sensu. Zatem „sens” i „wartość" stają się w stosunku do siebie właściwościami zamiennymi, gdzie sens raz jest figura, a wartość tłem, i odwrotnie. Wolę posiadania sensu uważa V. E. Frankl za pierwszorzędną siłę motywacyjną. Nie da się jednak sensu życia udowodnić empirycznie, ponieważ w miarę zbliżania się do niego oddala się jak horyzont. W rzeczywistości sens jest wynikiem rozumowania graniczącym z intuicją, a wyraża właściwość jakościową egzystencji spełnionej ${ }^{28}$. Tym zaś, co decyduje o rozpoznaniu wartości i doświadczeniu konieczności, jest sumienie, które określa V. E. Frankl jako „organ sensu”. Jest ono prelogiczne w tym znaczeniu, że wszelkie autentyczne wybory wartości dokonywane są bez refleksji, czyli nieświadomie. Dzieje się tak, ponieważ sumienie w bezpośredniej rzeczywistości swego działania nie poddaje się bez reszty racjonalizacji, można ją dokonać dopiero „po” działaniu (ex post). Zdaniem V. E. Frankla, racjonalność dotyczy tego, co jest, a sumienie tego, co dopiero ma być urzeczywistnione ${ }^{29}$. $\mathrm{W}$ jego rozumieniu decyzje sumienia wypływają $\mathrm{z}$ intuicyjnego uchwycenia przez osobę „powinności bytowej”30, a nie tylko jej racjonalnego rozpoznania.

Wydaje się zatem, że w tym przypadku wybór zasadniczy byłby stopniowym otwieraniem się człowieka na ostateczne poczucie sensu życia, w którym obecny jest w sposób nieuświadomiony Bóg. W takim razie osoba, która jest zaangażowana $\mathrm{w}$ stawanie się coraz bardziej wolną dla prawdy i ostatecznego sensu, nie potrzebuje długich refleksji przed podjęciem decyzji spójnej ze swoim zaangażowaniem, bowiem taki wybór wypływa raczej spontanicznie z intymnej głębi osoby, w której jest ukryty Bóg ${ }^{31}$. W rzeczywistości, to On jest źródłem i fundamentem prawdziwej wolności człowieka, która posiada swoje wewnętrzne uwarunkowania, a także uwarunkowania zewnętrzne, czyli socjo-kulturowe.

${ }^{26}$ Wartościowanie jest wielowymiarową predyspozycją funkcjonalną podmiotu: kognitywna, emocjonalną i egzystencjalną. V. E. Frankl uważa, iż człowiek zagubił zdolność do podmiotowych wyborów i decyzji. Por. K. Popielski, dz. cyt., s. 46-47.

${ }^{27}$ V. E. Frankl, Człowiek wolny..., s. 284.

${ }^{28}$ Por. K. Popielski, dz. cyt., s. 44-48.

${ }^{29}$ Por. A. Gałdowa, Powszechność i wyjatek. Rozwój osobowości człowieka dorosłego, Kraków 1992, s. 77-78.

${ }^{30}$ Por. V. E. Frankl, Nieuświadomiony Bóg, Warszawa 1978, s. 27.

${ }^{31}$ Por. B. Häring, dz. cyt., s. 218-219. 
Erich Fromm ${ }^{32}$ w swojej teorii „dialektycznego humanizmu”, w której łączył zainteresowania historii, socjologii, antropologii i filozofii z psychoanaliza, ukazał wpływ czynników socjo-kulturowych na rozwój wolności człowieka i możliwości decydowania o sobie ${ }^{33}$. Stwierdza on, że „zrozumienie psychiki człowieka musi opierać się na analizie jego potrzeb, wynikających z warunków jego egzystencji" ${ }^{34}$. Jego zdaniem, potrzeby - powiązań, transcendencji, zakorzenienia, tożsamości, orientacji i stymulacji - posiadają swój obiektywny charakter. Nie są wytworem społeczeństwa, ale zostały raczej osadzone w naturze ludzkiej przez ewolucję. Rozwój tych potrzeb jest uwarunkowany socjo-kulturowo. A zatem osobowość człowieka rozwija się stosownie do warunków, jakie stwarza mu społeczeństwo. Przystosowanie jednostki do społeczeństwa ${ }^{35}$ stanowi kompromis pomiędzy potrzebami wewnętrznymi a wymaganiami zewnętrznymi. W takiej interakcji dana osoba rozwija w sobie określony charakter, czyli układ umożliwiający orientację w świecie. Charakter społeczny obejmuje ,zasadnicze jądro struktury charakteru większości członków grupy, które rozwinęło się jako rezultat podstawowych doświadczeń i sposobu życia wspólnego tej grupy" ${ }^{36}$. Można zatem powiedzieć, że wewnętrzne potrzeby motywują człowieka do podejmowania konkretnych decyzji, dzięki którym staje się on przede wszystkim odpowiedzialny za samookreślenie swojej osoby, a także odbudowanie swojej jedności ze światem i społeczeństwem.

\section{Psychologiczno-pedagogiczne implikacje wolności i wyboru zasadniczego}

Ludzie z upływem stuleci uzyskiwali coraz więcej wolności, ale jednocześnie stawali się coraz bardziej osamotnieni. „Wraz ze społeczno-ekonomiczym i religijnym różnicowaniem się społeczeństw rozsypał się monopol w zakresie decyzji życiowych, koncepcji osiągnięć, religii czy tożsamości osobistej”37. Z jed-

${ }^{32}$ Przedmiotem refleksji psychologicznej E. Fromma nie jest kwestia zaspokojenia lub frustracji jakiejś potrzeby, co jest widoczne w teorii instynktów Z. Freuda, ale jakość związku człowieka ze światem, którą nazywa on przystosowaniem dynamicznym. Można jednak powiedzieć, że determinizm biologiczny prezentowany przez Z. Freuda został zastapiony przez determinizm socjo-ekonomiczno-kulturowy E. Fromma, który ukazuje alienujący wpływ społeczeństwa na jednostkę, a także ostrzega przed destrukcyjną rolą kultury. Por. P. K. Oleś, dz. cyt., s. 88.

${ }^{33}$ Por. C. S. Hall, G. Lindzey, J. B. Campbell, dz. cyt., s. 154-155.

${ }^{34}$ E. Fromm, Zdrowe społeczeństwo, thum. A. Tanalska-Dulęba, Warszawa 1996, s. 39.

${ }^{35}$ E. Fromm w następujących tezach podkreśla związek człowieka ze społeczeństwem: ludzie posiadają wrodzoną naturę; społeczeństwo jest stworzone przez ludzi w celu urzeczywistnienia wrodzonej natury; żadne dotychczasowe społeczeństwo nie zaspokaja podstawowych potrzeb egzystencji ludzkiej; możliwe jest stworzenie takiego społeczeństwa. Por. C. S. Hall, G. Lindzey, J. B. Campbell, dz. cyt., s. 157-159.

${ }^{36}$ E. Fromm, Ucieczka od wolności, tłum. O. i A. Ziemilscy, Warszawa 2000, s. 257.

${ }^{37}$ P. K. Oleś, dz. cyt., s. 85. 
nej strony powiększył się zakres ludzkiej wolności, a z drugiej - pogłębiło się oddzielenie człowieka od świata natury, a więc od tych instynktów, które podpowiadały mu, jak dokonywać właściwych wyborów, co robić, w jaki sposób żyć. Dojrzałym sposobem rozwiązania dylematu wolności jest zjednoczenie się z ludźmi w duchu miłości i wspólnej pracy. Wówczas osoba podejmuje wyzwanie miłości i trud indywidualnych wyborów, godząc się na lęk związany z podejmowaniem indywidualnej odpowiedzialności, a równocześnie znajdując oparcie w ponadindywidualnej wartości działań ludzkich ${ }^{38}$. Oznacza to, że człowiek w trakcie adaptacji do okoliczności zewnętrznych zyskuje nowe autonomiczne właściwości psychiczne, które kształtują jego uczucia i postępowanie. Proces ten dokonuje się $\mathrm{w}$ interakcji pomiędzy kulturą a biologicznym wyposażeniem człowieka ${ }^{39}$.

Jednak człowiek w poszukiwaniu bezpieczeństwa dokonuje negatywnych (niezdrowych) wyborów, które w rzeczywistości są ucieczką od rozwoju wolności i utratą osobowości ${ }^{40}$. Ten mechanizm ucieczki od rozwoju wolności i dezintegracji osobowej polega na redukowaniu lęku i poszukiwaniu bezpieczeństwa kosztem osobistej odpowiedzialności za kształt własnego życia. U podłoża tych negatywnych wyborów człowieka znajdują się trojakie czynniki: autorytaryzm, destruktywność, autonomiczny konformizm. W przypadku dokonania negatywnego wyboru człowiek nakłada na siebie nowe więzy ograniczające jego wolność, co w konsekwencji prowadzi do różnych form dezintegracji osobowej ${ }^{41}$.

Zdaniem E. Fromma, problematyki ludzkiej wolności i ludzkiego wyboru nie można ograniczyć tylko do rozważań czysto psychologicznych, ale należy ją powiązać z moralnym problemem życia, a także z wychowaniem moralnym. Chodzi bowiem o wybór pomiędzy postępem a regresem, miłością a nienawiścią, niezależnością a zależnością. W takich przypadkach prawdziwa wolność to nic innego jak pójście za głosem rozumu, zdrowia, sumienia, a odrzucenie głosu irracjonalnych uczuć ${ }^{42}$. Dlatego też każda forma negatywnego wyboru jest jaką́s próbą ucieczki przed ciężarem własnego człowieczeństwa, jest w gruncie rzeczy utratą siebie samego. Jest również wyeliminowaniem tego, co specyficznie ludzkie, rozumu, miłości i wolności, a każdy negatywny wybór prowadzi w stronę coraz większego rozdarcia pomiędzy ludzką egzystencją a esencją człowieka ${ }^{43}$.

Niektórzy ludzie nie są zdolni ani do wyboru dobra, ani do wyboru zła, ponieważ równowaga sił, jaka istnieje pomiędzy różnymi elementami ich charakteru, nie pozostawia żadnego wyboru. Jednak u większości ludzi wybór jest rzeczywiście możliwy, ponieważ jego akt stanowi rezultat sprzecznych tendencji o odpowiedniej

\footnotetext{
${ }^{38}$ Por. tamże, s. 86.

${ }^{39}$ Por. E. Fromm, Ucieczka od wolności..., s. 257-276.

${ }^{40}$ Por. tamże, s. 38-39.

${ }^{41}$ Por. C. S. Hall, G. Lindzey, J. B. Campbell, dz. cyt., s. 155-156.

${ }^{42}$ Por. E. Fromm, Serce człowieka. Jego niezwykła zdolność do dobra i zła, Warszawa-

${ }^{43}$ Por. tamże, s. 148.
} -Wrocław 1996, s. 129. 
sile $^{44}$. Ostatecznie E. Fromm twierdzi, że wśród wielu specyficznie ludzkich potrzeb istnieje również potrzeba posiadania układu orientacji, czci i światopoglądu, by uniknąć obłędu: ,pierwszą i bardziej fundamentalną potrzebą jest potrzeba posiadania jakiegokolwiek układu odniesienia, niezależnie od jego prawdziwości. Jeśli człowiek nie ma takiego subiektywnie zadowalającego układu odniesienia, nie może być psychicznie zdrów. Na drugim poziomie potrzeba ta to pragnienie, aby za pomocą rozumu pozostawać w kontakcie z rzeczywistością, pojmować świat obiektywnie"45. Tym samym w procesie dokonywania wyboru niezwykle ważne jest rozpoznanie świadomych, a przede wszystkim nieświadomych inklinacji. E. Fromm szczególną uwagę zwraca na proces uświadomienia w ludzkim akcie wyboru, który powinien dotyczyć uświadomienia tego, co dobre i złe; uświadomienia użycia właściwego środka do realizacji celu; odkrycia nieuświadomionych pragnień; uświadomienia rzeczywistych możliwości; uświadomienia konsekwencji możliwych wyborów; uświadomienia sobie konieczności działania woli" ${ }^{46}$.

W psychologii coraz częściej mówi się o tym, iż bogactwo ludzkiej świadomości nie sprowadza się tylko do pojęciowego poznania. Przykładem tego może być stanowisko W. Gruehna, który stwierdza, że człowiek poznaje Boga nie tylko pojęciowo, ale doświadcza Go całą swoją jaźnią w przeżyciu religijnym. Oznacza to, że w poznaniu Boga biorą udział nie tylko poszczególne władze, ale cała istota (jaźń) człowieka jest zanurzona w tym poznaniu. Zatem pojęcie Boga i funkcja jaźni są ze sobą nierozerwalnie powiązane. Można w tym przypadku mówić o dwóch momentach poznania - myślowym i osobistym ${ }^{47}$. W ludzkiej świadomości to, co świadome, wywodzi się z tego, co podświadome, a podświadome z tego, co nieświadome. Dlatego też należy wnioskować, że ludzkie „ja" może być pojmowane wielopiętrowo, stanowiąc podmiot zjawisk nie tylko świadomych, ale także podświadomych i nieświadomych. Pomiędzy tymi kręgami zależności zachodzą nieustanne odniesienia ${ }^{48}$. Wydaje się zatem, że wychowanie moralne człowieka winno być wychowaniem integralnym, obejmującym wszystkie sfery w człowieku, a więc świadome, półświadome i podświadome przejawy życia psychicznego. Odróżnienie w człowieku różnych sfer świadomości prowadzi, według wielu psychologów, do rozróżnienia w człowieku centrum osobowości od istniejących warstw bardziej lub mniej peryferyjnych psychologicznej świadomości. Warto przy tej okazji dodać, że ludzkie działanie znajduje się niekiedy pod wpływem motywów nieświadomych, pochodzących z różnych warstw świadomości, chociaż nie utożsamiają się one z motywami świadomymi

${ }^{44}$ Por. tamże, s. $130-131$.

${ }^{45}$ E. Fromm, Szkice z psychologii religii, thum. J. Prokopiuk, Warszawa 1966, s. 66-67.

${ }^{46}$ Por. E. Fromm, Serce czlowieka ..., s. 131-132.

${ }^{47}$ Por. W. Gruehn, Religijność współczesnego człowieka, Warszawa 1966, s. 90-91.

${ }^{48}$ Por. F. Bogdan, Wybór zasadniczy w religijno-moralnym życiu człowieka, w: Być człowiekiem. Powołanie człowieka, t. 3, Poznań-Warszawa 1974, s. 146-147. 
i rzeczywiście decydującymi ${ }^{49}$. Trzeba jednak pamiętać o tym, że do moralnego postępowania nie jest konieczne, aby wszystkie motywy skłaniające do działania były w pełni świadome.

Wobec problematyki rozwoju ludzkiej wolności i wyboru człowieka E. Fromm przyjmuje stanowisko alternatywizmu, ponieważ „wolność jednostki ludzkiej leży w jej możliwości wyboru wśród istniejących realnych możliwości (alternatyw), jakie są jej dane"50. Stąd też prawdziwa wolność jest oparta na uświadomieniu alternatyw i ich konsekwencji. E. Fromm uważa, że indeterminizm nie istnieje, istnieje czasami determinizm, a czasami alternatywizm oparty na ludzkim zjawisku świadomości. W praktyce życia oznacza to, że im człowiek posiada większą wiarę w siebie, większy poziom zintegrowania osobowego, zwiększa się również zdolność dokonywania właściwego wyboru, aż do wykształcenia w sobie zdolności do wyboru dobra. Natomiast akty poddaństwa i tchórzostwa nie tylko są drogą do dalszych ustępstw, ale mogą doprowadzić do utraty zdolności wyboru. To właśnie pomiędzy tymi stanami uzyskania zdolności wyboru lub utraty tej zdolności istnieje cała gama różnorodnych wyborów, pośród których szczególne miejsce zajmują wybory moralne ${ }^{51}$.

Według R. Maya, dystansowanie się terapeuty od zagadnień moralnych czy problematyki aksjologicznej jest nieuczciwe, ponieważ z jednej strony odcina się on od wartości, a z drugiej strony i tak ,przemyca swoje własne wartości”'52, by w rzeczywistości zaproponować jakąś pustkę aksjologiczną. Próbą wyjścia z tej aksjologicznej pustki może być poszukiwanie głębszego zrozumienia problematyki rozwoju ludzkiej wolności, która pojmowana jest jako zdolność uświadamiania sobie własnej osoby otwartej na świat i umiejącej się w nim poruszaćs ${ }^{53}$. Wydaje się zatem, że pogłębienie świadomości samego siebie jest nierozerwalnie związane ze wzrostem świadomości świata i odpowiedzialności za niego. To dzięki samoświadomości człowiek potrafi dokonywać „,przerw” w łańcuchu bodźców i reakcji, a także dokonywać świadomych wyborów, które wyrażają jego wolność. Egzystencjalna prawda o ludzkiej samoświadomości implikuje prawdę o ludzkiej samotranscendencji jako możliwości podejmowania osobowych wyborów, dzięki którym człowiek określa siebie, określa swoją osobową tożsamość ${ }^{54}$. Proces kształtowania się ludzkiej tożsamości ma ogromne znaczenie w tworzeniu się fundamentów zasadniczego wyboru człowieka. Tylko jednostka z integralnie ukształtowana osobowością (tożsamością) jest w stanie dokonać głębokiego samookreślenia (autodeterminacji) swojej osoby wobec świata obiektywnie istniejących wartości.

49 Por. H. Reiners, Grundintention und sittliches Tun, Freiburg-Basel-Wien 1966, s. $169-188$.

${ }^{50}$ E. Fromm, Serce człowieka..., s. 142.

${ }^{51}$ Por. tamże, s. $135-142$.

${ }^{52}$ R. May, Psychologia i dylemat ludzki, tłum. T. Mieszkowski, Warszawa 1989, s. 191.

${ }^{53}$ Por. tamże, s. 196.

${ }^{54}$ Por. R. May, O istocie człowieka. Szkice z psychologii egzystencjalnej, thum. M. Moryń, Z. Wiese, Poznań 1995, s. 180-189. 


\section{Podsumowanie}

Eksplikacja zagadnienia wolności i osobowego wyboru w niektórych nurtach psychologii humanistyczno-egzystencjalnej potwierdziła prawdę o istnieniu zasadniczego wyboru, poprzez który człowiek określa sens i podstawowy kierunek rozwoju swojego życia. Doświadczenie sensu życia zakłada zawsze moment dynamiki wyboru, akceptacji i zaangażowania się na rzecz wartości egzystencjalnie doniosłych. To właśnie współczesna psychologia, podejmując badania nad świadomością i wolnością człowieka, odkryła sferę wyborów głębokich, które określają i kierują wyborami konkretnymi. Odróżniono w człowieku osobowe centrum (najgłębsza warstwa) od warstw peryferyjnych (powierzchownych), ukazując jednocześnie zależność pomiędzy tym, co nieświadome, podświadome i świadome. W ten sposób ukazano, że zasadniczy wybór człowieka jest sprawą działania całego podmiotu, a nie tylko jednej z jego warstw. Jest to o tyle ważne, że w niektórych nurtach psychologii egzystencjalno-humanistycznej próbuje się poddać analizie nie tyle wyizolowane pojedyncze decyzje, ile raczej całą rzeczywistość motywacji człowieka, sensu jego życia, by wydobyć z podświadomości to, co wpływa na podjęcie decyzji zasadniczej. W takiej perspektywie zasadniczy wybór człowieka jawi się jako wybór, który ustanawia „nowe” transcendentne kryterium wyboru, będące podstawą samookreślenia się (autodeterminacji) osoby.

Warto zauważyć, że wolny wybór jednostki nie jest kwestią tylko części umysłu albo jaźni kontrolującej umysł, ale jest sprawą działania całego podmiotu, całej osoby. Wydaje się zatem, że niewłaściwe ujęcie problematyki wolności, a tym samym ludzkiego wyboru, wynika z błędu metodologicznego, zakładającego rozbicie człowieka na różne warstwy, fragmenty czy podstruktury np.: id, ego, superego. W rzeczywistości człowiek jest „całością”, czyli jest podmiotem charakteryzującym się jednością i spójnością. Należałoby wobec tego rozumieć wybór zasadniczy jako centralizację poszczególnych decyzji w podstawowym wyborze, który obejmuje całą osobę ludzką. Wobec tego celem wychowania byłoby kształtowanie integralnej osobowości (tożsamości) człowieka w taki sposób, by w oparciu o nią mógł on podejmować trwałe i odpowiedzialne decyzje, umożliwiające realizację ,projektu życia”, życiowego powołania. W związku z tym należy postulować, by sfera psychiczna człowieka była pojmowana w szerokim aspekcie wychowania, w którym problematyka wolności i wyboru zasadniczego człowieka odgrywałyby fundamentalną rolę w integralnym rozwoju osoby ludzkiej. 


\section{Psychological Conditioning of the Development of the Human Freedom and of Basic Human Choice (Summary)}

Some currents of humanistic and existential psychology by their explication of the problem of freedom and of personal choice have affirmed the truth of existence of a basic option, by which the human being may assign the meaning and the fundamental direction of his/her life. The experience of the meaningfulness of life implies always the moment of choice, of acceptance, and of personal involvement in the existentially essential values. It has been contemporary psychology, which while promoting and deepening the research on human consciousness and on human freedom, has discovered the sphere of deeper choices which define and guide concrete decisions of men/women. It has been distinguished then, between the personal centre of the human being (its deepest and fundamental layer) and peripheral layers (near-surface layers); at the same time the relations of dependence between the unconscious, the subconscious and the conscious has been stated. In this way it has been showed, that the basic choice of the human being touches the whole subject, and depends not only on one of its parts of on isolated, single decisions. So it is to demand, that the psychical sphere of the human being be conceived within a broad aspect of pedagogic, in which the problems of freedom and of fundamental choice would play a decisive role within the integral development of the human being. 